\title{
Thermobifida halotolerans sp. nov., isolated from a salt mine sample, and emended description of the genus Thermobifida
}

\author{
Correspondence \\ Wen-Jun Li \\ wjli@ynu.edu.cn \\ or \\ liact@hotmail.com
}

\author{
Ling-Ling Yang, ${ }^{1} \dagger$ Shu-Kun Tang, ${ }^{1} \dagger$ Yu-Qin Zhang, ${ }^{1,2}$ Xiao-Yang Zhi, \\ Dong Wang, ${ }^{3} \mathrm{Li}-\mathrm{Hua} \mathrm{Xu}^{1}$ and Wen-Jun $\mathrm{Li}^{1,4}$
}

\author{
${ }^{1}$ The Key Laboratory for Microbial Resources of the Ministry of Education, PR China, and \\ Laboratory for Conservation and Utilization of Bio-Resources, Yunnan Institute of Microbiology, \\ Yunnan University, Kunming 650091, PR China \\ ${ }^{2}$ Institute of Medicinal Biotechnology, Chinese Academy of Medical Sciences and Peking Union \\ Medical College, Beijing 100050, PR China \\ ${ }^{3}$ Science College, Honghe University, Mengzi, Yunnan 661100, PR China \\ ${ }^{4}$ Guangdong Key Laboratory of Marine Materia Medica, South China Sea Institute of Oceanology, \\ Chinese Academy of Sciences, Guangzhou 510301, PR China
}

The actinomycete strain YIM $90462^{\top}$ was isolated from a salt mine sample collected from Yunnan province, south-west China. Comparative 16S rRNA gene sequence analysis demonstrated that the isolate, which had sequence similarities of more than $97 \%$ to Thermobifida alba, Thermobifida fusca and Thermobifida cellulosilytica, was a candidate member of the genus Thermobifida. Subsequently, a polyphasic approach was used to clarify the taxonomic position of strain YIM $90462^{\top}$. Its diagnostic diamino acid was meso-diaminopimelic acid and whole-cell sugars contained galactose, xylose and glucose. The predominant menaquinones were $\mathrm{MK}-10\left(\mathrm{H}_{6}\right)$ and MK-10 $\left(\mathrm{H}_{8}\right)$. The major fatty acids were iso- $\mathrm{C}_{16: 0}$ and anteiso- $\mathrm{C}_{17: 0}$. Results of DNA-DNA hybridizations and physiological and biochemical tests enabled genotypic and phenotypic differentiation of strain YIM $90462^{\top}$ from the three Thermobifida species with validly published names. Consequently, it is proposed that strain YIM $90462^{\top}$ should be recognized as a representative of a novel species of Thermobifida, Thermobifida halotolerans sp. nov. The type strain is YIM $90462^{\top}\left(=\mathrm{KCTC} 19123^{\top}=\mathrm{DSM} 44931^{\top}\right)$. In addition, an emended description of the genus Thermobifida is presented.
The establishment of the genus Thermobifida (Zhang et al., 1998) was based on the reclassification of Thermobifida alba and Thermobifida fusca, which were formerly classified as Thermomonospora species (Cross \& Goodfellow, 1973; McCarthy \& Cross, 1984). Later, Thermobifida cellulosilytica was described by Kukolya et al. (2002). All three Thermobifida species were isolated from manure heaps, composts or damp stored hay and present outstanding cellulose decomposition abilities. T. fusca YX is used as a model organism for studies of aerobic, thermophilic,

†These authors contributed equally to this work.

Abbreviations: DAP, diaminopimelic acid; DPG, diphosphatidylglycerol; PC, phosphatidylcholine; PE, phosphatidylethanolamine; PG, phosphatidylglycerol; PI, phosphatidylinositol; PME, phosphatidylmethylethanolamine.

The GenBank/EMBL/DDBJ accession number for the 16S rRNA gene sequence of strain YIM $90462^{\top}$ is EU250489. cellulolytic bacteria and a complete genome is also available for this strain (Wilson, 2004; Lykidis et al., 2007).

Strain YIM $90462^{\mathrm{T}}$ was isolated from a salt mine sample, collected from Yunnan province, south-west China, after 3 weeks incubation at $45{ }^{\circ} \mathrm{C}$ on modified ISP medium 4 containing $10 \% \mathrm{NaCl}(\mathrm{w} / \mathrm{v})$. In view of its thermotolerant and halotolerant capabilities, this strain was studied further and its phylogenetic position was elucidated. Extraction of genomic DNA and amplification of the 16S rRNA gene were done as described by $\mathrm{Li}$ et al. (2007). The nearly complete 16S rRNA gene sequence of strain YIM $90462^{\mathrm{T}}$ was determined and BLAST (Altschul et al., 1997) searches revealed that it possessed significant sequence similarities to those of Thermobifida species. Sequence similarities were determined by using CLUSTAL_X (Thompson et al., 1997). Strain YIM $90462^{\mathrm{T}}$ showed high sequence similarities to $T$. alba DSM $43795^{\mathrm{T}}(98.2 \%)$, T. cellulosilytica DSM $44535^{\mathrm{T}}$ $(97.8 \%)$ and T. fusca DSM $43792^{\mathrm{T}}(97.0 \%)$. Given the 
Table 1. Differential phenotypic properties of strain YIM $90462^{\top}$ and the type strains of Thermobifida species

Strains: 1, YIM $90462^{\mathrm{T}}$; 2, T. alba DSM $43795^{\mathrm{T}}$; 3, T. fusca DSM 43792 ${ }^{\mathrm{T}}$; 4, T. cellulosilytica DSM $44535^{\mathrm{T}}$. All tested strains grow well in the absence of $\mathrm{NaCl}$ and at $45{ }^{\circ} \mathrm{C}$ and $\mathrm{pH}$ 7-8. All strains contain the phospholipids DPG, PME, PC, PI, PG and PL. All are positive for degradation of Tweens 20 and 80 and hydrolysis of starch and cellulose; melanin and $\mathrm{H}_{2} \mathrm{~S}$ production, gelatin liquefaction and urease production are negative. Cellobiose, D-galactose, D-glucose, raffinose, sucrose and D-xylose are utilized as sole carbon sources for growth; myo-inositol and sorbitol are not utilized.

\begin{tabular}{|c|c|c|c|c|}
\hline Characteristic & 1 & 2 & 3 & 4 \\
\hline Arial mycelium on ISP2 & - & - & - & + \\
\hline $\begin{array}{l}\text { Temperature range for } \\
\text { growth }\left({ }^{\circ} \mathrm{C}\right)\end{array}$ & $20-50$ & $20-50$ & $28-55$ & $28-55$ \\
\hline $\mathrm{pH}$ range for growth & $6-9$ & $6-9$ & $6-9$ & $6-10$ \\
\hline $\begin{array}{l}\text { Maximum } \mathrm{NaCl} \\
\text { concentration }(\%, \mathrm{w} / \mathrm{v})\end{array}$ & 10 & 3 & 5 & 3 \\
\hline Milk coagulation & - & + & + & + \\
\hline Milk peptonization & - & + & + & + \\
\hline Nitrate reduction & + & - & - & - \\
\hline \multicolumn{5}{|l|}{ Carbon source utilization } \\
\hline D-Arabinose & + & + & - & - \\
\hline D-Fructose & - & - & + & + \\
\hline Glycerol & + & + & + & - \\
\hline Lactose & - & - & + & + \\
\hline Maltose & - & - & + & + \\
\hline D-Mannose & - & - & + & + \\
\hline L-Rhamnose & - & + & - & + \\
\hline D-Ribose & - & - & - & + \\
\hline L-Sorbose & - & + & - & - \\
\hline Trehalose & + & - & + & + \\
\hline Xylitol & - & + & - & - \\
\hline Presence of PE & + & - & + & + \\
\hline Menaquinones $(>5 \%)$ & $\begin{array}{l}10\left(\mathrm{H}_{4}\right)(11.1 \%), 10\left(\mathrm{H}_{6}\right) \\
(30.0 \%), 10\left(\mathrm{H}_{8}\right)(41.1 \%)\end{array}$ & $\begin{array}{c}10\left(\mathrm{H}_{6}\right)(28.6 \%), 10\left(\mathrm{H}_{8}\right) \\
(41.7 \%), 11\left(\mathrm{H}_{6}\right)(7.5 \%), \\
11\left(\mathrm{H}_{8}\right)(9.7 \%)\end{array}$ & $\begin{array}{c}10\left(\mathrm{H}_{6}\right)(9.6 \%), 10\left(\mathrm{H}_{8}\right) \\
(45.3 \%), 11\left(\mathrm{H}_{6}\right)(5.2 \%) \\
11\left(\mathrm{H}_{8}\right)(17.2 \%), 12 \\
(15.8 \%)\end{array}$ & $\begin{array}{c}10\left(\mathrm{H}_{6}\right)(22.6 \%), \\
10\left(\mathrm{H}_{8}\right)(58.2 \%) \\
11\left(\mathrm{H}_{8}\right)(10.5 \%)\end{array}$ \\
\hline Major fatty acids $(>10 \%)^{*}$ & $\begin{array}{l}\mathrm{i}-\mathrm{C}_{16: 0}(51.1 \%), \\
\text { ai-C }_{17: 0}(11.7 \%)\end{array}$ & $\begin{array}{l}\mathrm{i}-\mathrm{C}_{16: 0}(24.4 \%), \\
\text { ai-C } \mathrm{C}_{17: 0}(29.1 \%)\end{array}$ & $\begin{array}{l}\mathrm{i}-\mathrm{C}_{16: 0}(38.5 \%) \\
\text { ai- } \mathrm{C}_{17: 0}(15.2 \%)\end{array}$ & $\begin{array}{c}\mathrm{i}-\mathrm{C}_{16: 0}(28.7 \%), \mathrm{i}-\mathrm{C}_{17: 0} \\
(26.1 \%), \text { ai- } \mathrm{C}_{17: 0} \\
(18.3 \%), \mathrm{i}-\mathrm{C}_{18: 0} \\
(12.2 \%)\end{array}$ \\
\hline $\begin{array}{l}\text { DNA G }+ \text { C content } \\
(\mathrm{mol} \%)\end{array}$ & 69.0 & 71.2 & 66.2 & 70.4 \\
\hline
\end{tabular}

$\star_{i}$, iso; ai, anteiso.

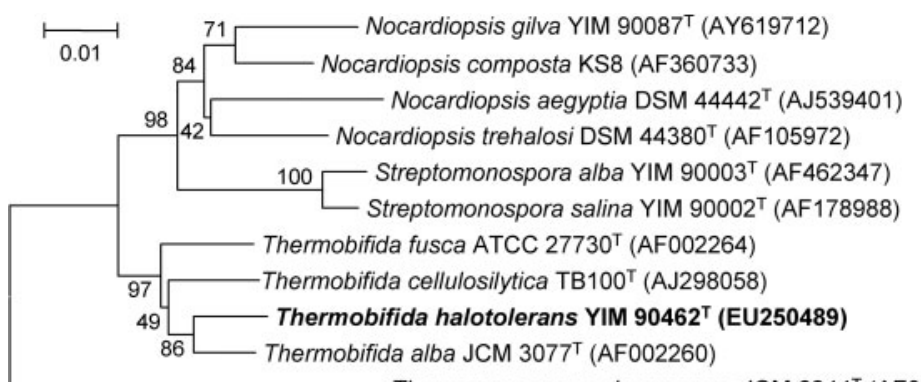

Thermomonospora chromogena JCM 6244 ${ }^{\top}$ (AF002261)
Fig. 1. Phylogenetic dendrogram obtained by neighbour-joining analysis based on $16 \mathrm{~S}$ rRNA gene sequences showing the position of strain YIM $90462^{\top}$ among phylogenetic neighbours. Bootstrap values (expressed as a percentage of 1000 replications) are given at nodes. Thermomonospora chromogena JCM $6244^{\top}$ was used as an outgroup. Bar, 0.01 substitutions per nucleotide position. 
high $16 \mathrm{~S}$ rRNA gene sequence similarities, all four strains were tested together in this study.

Cultural characteristics of strain YIM $90462^{\mathrm{T}}$ and the other three Thermobifida type strains were observed using ISP media 2, 3, 4 and 5, Czapek's agar, potato agar and nutrient agar. The colours of the aerial and substrate mycelia were determined by the ISCC-NBS colour charts (standard sampled no. 2106) (Kelly, 1964). Cultural characteristics were similar among the four tested strains. All of them grew on most media tested, apart from Czapek's agar. They grew well on ISP2, potato agar and nutrient agar plates, but poorly on ISP media 3,4 and 5 . In addition, they all produced white aerial mycelium on nutrient agar medium. However, there were some differences between the strains. Isolate YIM $90462^{\mathrm{T}}$ produced aerial mycelium only on nutrient agar medium, just like T. alba and T. fusca, but $T$. cellulosilytica also produced aerial mycelium on ISP2 (Table 1). Morphological features of YIM $90462^{\mathrm{T}}$ were examined by scanning electron microscopy (XL30, ESEMTMP; Philips) of 2-week-old cultures grown on nutrient agar medium. Morphological features of YIM $90462^{\mathrm{T}}$ are consistent with those of members of the genus Thermobifida described previously (Kukolya et al., 2002; Kroppenstedt \& Evtushenko, 2006). Substrate mycelium was well developed, but not fragmented. Single, smooth-ridged spores were produced on the tips of repeatedly branched sporophores to form dense spore clusters on the aerial mycelium.

The physiological and biochemical characteristics of the four strains were tested. Growth was assessed on ISP2 agar plates at various temperatures $[0,4,10,15,20,28-37$ (at $1{ }^{\circ} \mathrm{C}$ intervals), 40, 45, 50, 55, 60 and $\left.65{ }^{\circ} \mathrm{C}\right]$. The ability of the strains to grow at various $\mathrm{NaCl}$ concentrations $(0$ $15 \%, \mathrm{w} / \mathrm{v}$, at intervals of $0.5 \%$ ) was examined using ISP2 as basal medium. The $\mathrm{pH}$ range and optimum for growth were tested from $\mathrm{pH} 4$ to 10 following the method described by $\mathrm{Xu}$ et al. (2005). Carbohydrate utilization was tested by using ISP medium 9 (Shirling \& Gottlieb, 1966) as basal medium. Each filter-sterilized compound was added to the medium to give a final concentration of $1.0 \%(\mathrm{w} / \mathrm{v})$. Detailed characteristics are given in Table 1 and in the species description. It was noticed that isolate YIM $90462^{\mathrm{T}}$ could tolerate up to $10 \%(\mathrm{w} / \mathrm{v}) \mathrm{NaCl}$. The outstanding cellulose-decomposing ability is the major characteristic feature of strains assigned to the genus Thermobifida (Kukolya et al., 2002). Strain YIM $90462^{\mathrm{T}}$ also showed high cellulase activity on crystalline cellulose and the clearing zones that were observed on CM-cellulosecontaining agar plates indicated the presence of a complete cellulose-degrading enzyme system. In addition, there was some evidence that strain YIM $90462^{\mathrm{T}}$ may be useful in enzymological studies (data not shown).

Chemotaxonomic properties (Table 1), including menaquinones (Collins et al., 1977; Groth et al., 1997), phospholipids (Minnikin et al., 1979; Collins \& Jones, 1980), whole-cell fatty acid pattern (Kroppenstedt, 1985), cell-wall amino acids and whole-cell sugars (Staneck \&
Roberts 1974), were analysed by standard methods. All four tested strains contained meso-diaminopimelic acid (mesoDAP) as the diagnostic diamino acid in the cell wall and galactose, xylose and glucose as whole-cell sugars. The phospholipids comprised diphosphatidylglycerol (DPG), phosphatidylmethylethanolamine (PME), phosphatidylcholine (PC), phosphatidylinositol (PI), phosphatidylglycerol (PG) and an unknown phospholipid. Strain YIM $90462^{\mathrm{T}}$, T. fusca DSM $43792^{\mathrm{T}}$ and T. cellulosilytica DSM $44535^{\mathrm{T}}$ also contained phosphatidylethanolamine (PE). The predominant menaquinones were $\mathrm{MK}-10\left(\mathrm{H}_{6}\right)$ and MK-10 $\left(\mathrm{H}_{8}\right)$. The fatty acid profiles differed among the four strains, but the major components were iso- $\mathrm{C}_{16: 0}$ and anteiso- $\mathrm{C}_{17: 0}$.

Multiple alignments with sequences of the most closely related actinobacterial strains were carried out using CLUSTAL_X (Thompson et al., 1997). The neighbour-joining phylogenetic tree was reconstructed by using the software package MEGA version 3.1 (Kumar et al., 2004) and evaluated by the bootstrap resampling method of Felsenstein (1985) with 1000 replicates. Phylogenetic analysis confirmed the placement of strain YIM $90462^{\mathrm{T}}$ in the genus Thermobifida (Fig. 1). Genomic hybridization experiments between strain YIM $90462^{\mathrm{T}}$ and T. alba DSM $43795^{\mathrm{T}}(33.8 \%)$, T. fusca DSM $43792^{\mathrm{T}}(50.2 \%)$ and T. cellulosilytica DSM $44535^{\mathrm{T}}(35.4 \%)$ were performed by using the method described by He et al. (2005) and repeated five times. These values were significantly lower than the $70 \%$ value considered to be the threshold for the delineation of genomic species (Wayne et al., 1987). The DNA G + C contents of strain YIM $90462^{\mathrm{T}}(69.0 \mathrm{~mol} \%), T$. alba DSM $43795^{\mathrm{T}}$ (71.2 mol\%), T. fusca DSM $43792^{\mathrm{T}}$ (66.2 mol\%) and T. cellulosilytica DSM $44535^{\mathrm{T}}(70.4 \%)$ were determined by reversed-phase HPLC of nucleosides according to Mesbah et al. (1989). These data for the G+C contents of members of the genus Thermobifida are very close to the results reported by Kukolya et al. (2002). The $\mathrm{G}+\mathrm{C}$ content of T. fusca DSM $43792^{\mathrm{T}}$ was significantly lower than those of other Thermobifida species. This result was confirmed by genome analysis of T. fusca YX, which revealed that the precise $\mathrm{G}+\mathrm{C}$ content of T. fusca YX was $67.5 \mathrm{~mol} \%$ (Lykidis et al., 2007).

Similarities in morphological characteristics, cell-wall amino acids, whole-cell sugars and DNA G + C contents between the four strains studied support the inclusion of strain YIM $90462^{\mathrm{T}}$ within the genus Thermobifida. However, the isolate could be distinguished from T. alba DSM $43795^{\mathrm{T}}$, T. fusca DSM $43792^{\mathrm{T}}$ and T. cellulosilytica DSM $44535^{\mathrm{T}}$ by its fatty acid profile, menaquinones and phospholipids and some physiological and enzymic properties (Table 1). DNA-DNA hybridization confirmed the differentiation between YIM $90462^{\mathrm{T}}$ and the other three species of Thermobifida at the species level. It is clear from the combined genotypic and phenotypic data shown that strain YIM $90462^{\mathrm{T}}$ should be classified as a representative of a novel species within the genus Thermobifida, Thermobifida halotolerans sp. nov. As a consequence of 
the characteristics of members of the genus Thermobifida that were examined in this study, the description of the genus Thermobifida needs to be emended.

\section{Emended description of Thermobifida Zhang et al. 1998}

The following features are observed, in addition to those given in the description by Zhang et al. (1998). The phospholipid pattern is complex, consisting of DPG, PME, PC, PI, PG and an unknown phospholipid; PE may occur. The predominant menaquinones are $\mathrm{MK}-10\left(\mathrm{H}_{6}\right)$ and $\mathrm{MK}$ $10\left(\mathrm{H}_{8}\right)$. The major fatty acids are iso- $\mathrm{C}_{16: 0}$ and anteiso$\mathrm{C}_{17: 0}$. Glucose, galactose and xylose are found in wholeorganism hydrolysates. The $\mathrm{G}+\mathrm{C}$ content of the genomic DNA is $66-72 \mathrm{~mol} \%$. Phylogenetically, the genus belongs to the family Nocardiopsaceae. The type species is Thermobifida alba (Locci et al. 1967) Zhang et al. 1998.

\section{Description of Thermobifida halotolerans sp. nov.}

Thermobifida halotolerans (ha.lo.to'le.rans. Gr. n. hals, halos salt; L. part. adj. tolerans tolerating; N.L. part. adj. halotolerans referring to the ability to tolerate high salt concentrations).

Aerobic, Gram-positive. Grows well on ISP medium 2, potato agar and nutrient agar plates and poorly on ISP media 3, 4 and 5. Does not grow on Czapek's agar. Substrate mycelium is well developed, but not fragmented. Aerial mycelium is only formed on nutrient medium. Produces single, smooth spores on aerial hyphae on the tips of dichotomously branched sporophores. Good growth occurs at $45{ }^{\circ} \mathrm{C}$ and $\mathrm{pH}$ 7.0-8.0. Positive for nitrate reduction, starch hydrolysis, cellulose hydrolysis and degradation of Tweens 20 and 80 , but negative for gelatin liquefaction, melanin production, milk peptonization and coagulation and $\mathrm{H}_{2} \mathrm{~S}$ and urease production. The following substrates are utilized as sole carbon sources: D-arabinose, cellobiose, D-galactose, D-glucose, glycerol, raffinose, sucrose, trehalose and D-xylose. D-Fructose, myo-inositol, lactose, maltose, D-mannose, L-rhamnose, D-ribose, sorbitol, L-sorbose and xylitol are not utilized. The whole-cell sugars are galactose, xylose and glucose. The diagnostic diamino acid is meso-DAP. The predominant menaquinones are MK-10 $\left(\mathrm{H}_{6}\right)$ and MK-10 $\left(\mathrm{H}_{8}\right)$. Phospholipids are DPG, PG, PE, PME, PC, PI and an unknown phospholipid. The major fatty acids $(>10 \%)$ are iso- $\mathrm{C}_{16: 0}(51.1 \%)$ and anteiso- $\mathrm{C}_{17: 0}(11.7 \%)$.

The type strain is YIM $90462^{\mathrm{T}}\left(=\mathrm{KCTC} 19123^{\mathrm{T}}=\mathrm{DSM}\right.$ $44931^{\mathrm{T}}$ ), isolated from a saline soil sample collected from Yunnan, south-west China. The DNA G $+\mathrm{C}$ content of the type strain is $69.0 \mathrm{~mol} \%$.

\section{Acknowledgements}

The authors are very grateful to Dr J. P. Euzéby for his advice on nomenclature and to Professor R. M. Kroppenstedt of the DSMZ for his kind provision of some reference type strains. This research was supported by the National Basic Research Program of China (project no. 2004CB719601), the Key Project of Chinese Ministry of Education (no. 206139), the National Natural Science Foundation of China (project no. 30600001) and the Yunnan Provincial Natural Science Foundation (project no. 2007C167M). W.-J. L. was also supported by the Program for New Century Excellent Talent in University (NCET).

\section{References}

Altschul, S. F., Madden, T. L., Schäffer, A. A., Zhang, J., Zhang, Z., Miller, W. \& Lipman, D. J. (1997). Gapped BLAST and PSI-BLAST: a new generation of protein database search programs. Nucleic Acids Res 25, 3389-3402.

Collins, M. D. \& Jones, D. (1980). Lipids in the classification and identification of coryneform bacteria containing peptidoglycans based on 2,4-diaminobutyric acid. J Appl Bacteriol 48, 459-470.

Collins, M. D., Pirouz, T., Goodfellow, M. \& Minnikin, D. E. (1977). Distribution of menaquinones in actinomycetes and corynebacteria. $J$ Gen Microbiol 100, 221-230.

Cross, T. \& Goodfellow, M. (1973). Taxonomy and classification of the actinomycetes. In Actinomycetales: Characteristics and Practical Importance, pp. 11-112. Edited by G. Sykes \& F. A. Skinner. London: Academic Press.

Felsenstein, J. (1985). Confidence limits on phylogenies: an approach using the bootstrap. Evolution 39, 783-789.

Groth, I., Schumann, P., Rainey, F. A., Martin, K., Schuetze, B. \& Augsten, K. (1997). Demetria terragena gen. nov., sp. nov., a new genus of actinomycetes isolated from compost soil. Int J Syst Bacteriol 47, 1129-1133.

He, L., Li, W., Huang, Y., Wang, L., Liu, Z., Lanoot, B., Vancanneyt, M. \& Swings, J. (2005). Streptomyces jietaisiensis sp. nov., isolated from soil in northern China. Int J Syst Evol Microbiol 55, 1939-1944.

Kelly, K. L. (1964). Inter-Society Color Council - National Bureau of Standards Color Name Charts Illustrated with Centroid Colors. Washington, DC: US Government Printing Office.

Kroppenstedt, R. M. (1985). Fatty acid and menaquinone analysis of actinomycetes and related organisms. In Chemical Methods in Bacterial Systematics (Society for Applied Bacteriology Technical Series, vol. 20), pp. 173-199. Edited by M. Goodfellow \& D. E. Minnikin. New York: Academic Press.

Kroppenstedt, R. M. \& Evtushenko, L. I. (2006). The family Nocardiopsaceae. In The Prokaryotes. A Handbook on the Biology of Bacteria, 3rd edn, vol. 3, pp. 754-795. Edited by M. Dworkin, S. Falkow, E. Rosenberg, K. H. Schleifer \& E. Stackebrandt. New York: Springer.

Kukolya, J., Nagy, I., Láday, M., Tóth, E., Oravecz, O., Márialigeti, K. \& Hornok, L. (2002). Thermobifida cellulolytica sp. nov., a novel lignocellulose-decomposing actinomycete. Int J Syst Evol Microbiol 52, 1193-1199.

Kumar, S., Tamura, K. \& Nei, M. (2004). MEGA3: integrated software for molecular evolutionary genetics analysis and sequence alignment. Brief Bioinform 5, 150-163.

Li, W.-J., Xu, P., Schumann, P., Zhang, Y.-Q., Pukall, R., Xu, L.-H., Stackebrandt, E. \& Jiang, C.-L. (2007). Georgenia ruanii sp. nov., a novel actinobacterium isolated from forest soil in Yunnan (China), and emended description of the genus Georgenia. Int J Syst Evol Microbiol 57, 1424-1428.

Locci, R., Baldacci, E. \& Petrolini, B. (1967). Contribution to the study of oligosporic actinomycetes. I. Description of a new species of Actinobifida: Actinobifida alba sp. nov. and revision of the genus. $G$ Microbiol 15, 79-91. 
Lykidis, A., Mavromatis, K., Ivanova, N., Anderson, I., Land, M., DiBartolo, G., Martinez, M., Lapidus, A., Lucas, S. \& other authors (2007). Genome sequence and analysis of the soil cellulolytic actinomycete Thermobifida fusca YX. J Bacteriol 189, 2477-2486.

McCarthy, A. J. \& Cross, T. (1984). A taxonomic study of Thermomonospora and other nonsporic actinomycetes. J Gen Microbiol 130, 5-25.

Mesbah, M., Premachandran, U. \& Whitman, W. B. (1989). Precise measurement of the $\mathrm{G}+\mathrm{C}$ content of deoxyribonucleic acid by highperformance liquid chromatography. Int J Syst Bacteriol 39, 159-167.

Minnikin, D. E., Collins, M. D. \& Goodfellow, M. (1979). Fatty acid and polar lipid composition in the classification of Cellulomonas, Oerskovia and related taxa. J Appl Bacteriol 47, 87-95.

Shirling, E. B. \& Gottlieb, D. (1966). Methods for characterization of Streptomyces species. Int J Syst Bacteriol 16, 313-340.

Staneck, J. L. \& Roberts, G. D. (1974). Simplified approach to identification of aerobic actinomycetes by thin-layer chromatography. Appl Microbiol 28, 226-231.
Thompson, J. D., Gibson, T. J., Plewniak, F., Jeanmougin, F. \& Higgins, D. G. (1997). The CLUSTAL_X windows interface: flexible strategies for multiple sequence alignment aided by quality analysis tools. Nucleic Acids Res 25, 4876-4882.

Wayne, L. G., Brenner, D. J., Colwell, R. R., Grimont, P. A. D., Kandler, O., Krichevsky, M. I., Moore, L. H., Moore, W. E. C., Murray, R. G. E. \& other authors (1987). International Committee on Systematic Bacteriology. Report of the ad hoc committee on reconciliation of approaches to bacterial systematics. Int J Syst Bacteriol 37, 463-464.

Wilson, D. B. (2004). Studies of Thermobifida fusca plant cell wall degrading enzymes. Chem $\operatorname{Rec} 4,72-82$.

Xu, P., Li, W.-J., Tang, S.-K., Zhang, Y.-Q., Chen, G.-Z., Chen, H.-H., Xu, L.-H. \& Jiang, C.-L. (2005). Naxibacter alkalitolerans gen. nov., sp. nov., a novel member of the family 'Oxalobacteraceae' isolated from China. Int J Syst Evol Microbiol 55, 1149-1153.

Zhang, Z., Wang, Y. \& Ruan, J. (1998). Reclassification of Thermomonospora and Microtetraspora. Int J Syst Bacteriol 48, 411-422. 